ness to Mrs. L. C. Krueger, to whom the credit for the analytical work is largely due.

Mass. INSTitute of Technology, Boston, Mass.

\title{
DETERMINATION OF URANIUM AND VANADIUM.
}

BY A. N. FinN.

Received July 30, Iģo6.

A STUDY of the ore carnotite; which is a potassium uranyl vanadate, repeatedly required the determination of uranium and vanadium. This led to a comparison of the various titration methods that have been suggested.

Bellohoubek ${ }^{1}$ refers to the reduction of uranium in solution by zinc and sulphuric acid and titration with potassium permanganate. Sutton, in the sixth edition of his "Volumetric Analysis," states that this method is very accurate if care is taken to insure complete reduction which requires from one-quarter to one-half an hour.

Determinations of uranium by this method in solutions of uranyl sulphate gave very satisfactory results provided the potassium permanganate solution was not more than twentieth-normal. When, however, uranium is to be determined from a complex mixture or an ore, great difficulty is found in securing the uranium in a form sufficiently pure for the titration. This is especially true in the presence of vanadium.

The general method of separating the uranium and vanadium from each other and from the various other elements in the ore, is to treat an acid solution of the ore with an excess of sodium carbonate, which precipitates the iron, aluminum, etc., and filter. The filtrate containing the uranium and vanadium is acidified, the carbon dioxide expelled by boiling and the solution is made alkaline with sodium, potassium or ammonium hydroxide. This precipitates the uranium as the corresponding uranate, while the vanadium remains in solution. The uranate is dissolved in sulphuric acid, reduced with zinc and titrated with permanganate. The solution of vanadium is acidified, reduced with sulphur dioxide and titrated with permanganate.

The precipitated uranate is gelatinous and it was found impossible to wash this precipitate free from vanadium, and since

${ }^{1} \mathrm{~J}$. pr. Chem. 99, $23 \mathrm{r}$. 
the uranate is slightly soluble it is not desirable to wash or redissolve it many times.

In view of this fact, it became necessary to find an accurate and, if possible, a quicker method for the separation and determination of uranium and vanadium.

This was accomplished by precipitating the uranium in alkaline solution as a phosphate. This precipitate, ammonium uranyl phosphate, is not gelatinous, is insoluble and may easily be washed free from vanadium.

To show that the volumetric method of titrating the reduced solutions with permanganate is consistent in itself, samples of uranium salts containing no vanadium were used and the following results were obtained:

Sample.

Solution No. I

Solution No.

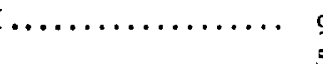

Grams.

9.5058

5.1820

5.0603

5.1570

Solution No. II.............. 10.294I

10.2839

Solution No. III

$$
\begin{array}{r}
11.7228 \\
4.4641
\end{array}
$$

Samples of solution No. III precipitated with ammonia, ignited and weighed as $\mathrm{U}_{3} \mathrm{O}_{8}$, gave the following results:
Grams.
3.81955
Per cent. $\mathrm{U}_{3} \mathrm{O}_{8}$.
5.3409
5.237
5.297

For vanadium, material free from uranium was used and the following results were obtained:

Sample.

Solution No. IV

Grams.

10.7412

10.4142

II. 3310

II. 4935

Solution No. V.............. I2.8359

12.6929

$15.205 \mathrm{I}$

14.1954

Sample No. VI............. 0.3311

0.4341

0.3004
Per cent. $\mathrm{V}_{2} \mathrm{O}_{5}$.

0.945

0.946

0.941

0.947

$1.33^{8}$

I. 340

r.349

I.339 
The method suggested for determining uranium and vanadium is, in detail, as follows:

Dissolve a sample of ore that does not contain more than 0.25 gram of $\mathrm{U}_{3} \mathrm{O}_{8}$ in sulphuric acid $(\mathrm{I}: 5)$ and evaporate to fumes of the acid. Cool, dilute, add an excess of sodium carbonate and boil until the precipitate settles well. Filter and wash with hot water. Dissolve the precipitate in the smallest possible amount of sulphuric acid, dilute, add an excess of sodium carbonate, boil, filter and wash. Acidify the combined filtrates and wash-waters with sulphuric acid. Add ammonium phosphate ( $0.5 \mathrm{gram}$ is usually sufficient), heat to boiling and make alkaline with ammonia, boil for a few minutes, filter and wash with hot water containing a little ammonium sulphate, which prevents the finely divided particles of the precipitate from passing through the paper.

The filtrates now contains the vanadium and the precipitate the uranium. Acidify the filtrate- with sulphuric acid, pass sulphur dioxide into it until it becomes blue, boil to expel the excess of sulphur dioxide and titrate while hot with permanganate. The iron factor of the permanganate solution multiplied by $\mathrm{I}_{63} \mathrm{I}$ gives the $\mathrm{V}_{2} \mathrm{O}_{5}$ factor or by 0.9159 gives the vanadium factor.

Dissolve the ammonium uranyl phosphate in sulphuric acid, add some granulated zinc and let the action continue vigorously for at least thirty minutes. Remove the undissolved zinc by filtering over asbestos, using a suction pump, and titrate at about $60^{\circ}$ with permanganate (twentieth-normal).

The iron factor of the permanganate solution multiplied by 2.5167 gives the $\mathrm{U}_{3} \mathrm{O}_{8}$ factor or by 2.133 gives the uranium factor.

By this method of separation, reducing the solutions and titrating with permanganate, the following results were obtained:

\begin{tabular}{|c|c|c|c|}
\hline \multirow{5}{*}{$\begin{array}{l}\text { Sample. } \\
\text { Solution No. VII. }\end{array}$} & Grams. & Per cent. $\mathrm{U}_{3} \mathrm{O}_{8}$. & Per cent. $\mathrm{V}_{2} \mathrm{O}_{5}$. \\
\hline & 10.7904 & 1.074 & 1.429 \\
\hline & 21.5602 & 1.068 & $\ldots$ \\
\hline & $15.092 \mathrm{I}$ & 1.085 & 1.407 \\
\hline & 10.6119 & 1.063 & 1.415 \\
\hline \multirow[t]{3}{*}{ Ore-carnotite $I . \ldots \ldots \ldots$} & 1.0002 & 11.793 & 6.363 \\
\hline & 1.0013 & $\ldots \ldots$ & 6.300 \\
\hline & 1.0004 & I 1.885 & $6.26 \mathrm{I}$ \\
\hline
\end{tabular}




\begin{tabular}{|c|c|c|c|}
\hline $\begin{array}{l}\text { Sample. } \\
\text { Ore-carnotite II. . . . . . . }\end{array}$ & $\begin{array}{l}\text { Grams. } \\
1.0009 \\
2.0005\end{array}$ & $\begin{array}{c}\text { Per cent. } \mathrm{U}_{8} \mathrm{O}_{8} \text {. } \\
6.755 \\
6.702\end{array}$ & $\begin{array}{c}\text { Per cent. } \mathrm{V}_{2} \mathrm{O}_{5} \text {. } \\
6.849 \\
6.526\end{array}$ \\
\hline Ore-carnotite III . . . . . . & $\begin{array}{l}1.0006 \\
1.0003\end{array}$ & $\begin{array}{l}4.873 \\
4.945\end{array}$ & $\begin{array}{l}5.128 \\
5.358\end{array}$ \\
\hline Ore-carnotite IV ........ & $\begin{array}{l}1.00045 \\
1.00025\end{array}$ & $\begin{array}{l}1.834 \\
1.728\end{array}$ & $\begin{array}{l}\cdots \\
\cdots\end{array}$ \\
\hline Ore carnotite $V \ldots \ldots \ldots$ & $\begin{array}{r}0.9994 \\
1.2004\end{array}$ & $\begin{array}{l}0.4094 \\
0.4205\end{array}$ & $\begin{array}{l}\cdots \\
\cdots\end{array}$ \\
\hline
\end{tabular}

\title{
THE SOLUBILITY OF SILVER CHLORIDE IN HYDRO- CHLORIC ACID AND IN SODIUM CHLORIDE SOLUTIONS.
}

\author{
BY WILLIAM EDWARD BARLOW. \\ Received August $\mathrm{I} 7,1906$.
}

IT Has been shown by Dudley ${ }^{1}$ that when sodium dioxide is fused in a silver crucible the metal is rapidly attacked, with the formation of a complex oxide.

In I902 I observed, in ignorance of Dudley's paper, the same action, and showed ${ }^{2}$ that when the melt is evaporated or heated with hydrochloric acid (as in the method of determining sulphur by means of fusion with sodium dioxide) the altered silver is converted into chloride, which dissolves (in amounts varying with the temperature and concentration) in the concentrated salt solution present. If the solution is then filtered, and allowed to stand, the greater part-but not the whole- of the silver chloride deposits on cooling. The barium sulphate precipitates from such determinations are almost certain to contain silver. When the solution is filtered hot, and barium chloride solution added before cooling, as in the ordinary sodium peroxide process for determining sulphur, the amount of silver in the barium sulphate may be considerable. In one case 0.03 gram silver chloride was extracted from such a precipitate. This would have occasioned an error of 0.2 per cent. in the sulphur content.

To ascertain the extent to which the reactions above mentioned go on under the conditions of a sodium peroxide fusion the following experiments were made:

I Am. Ch. J. 28, 62 (1902).

2 Inaugural Dissertation, Göttingen, June, 1903. 